\title{
Bank Liquidity Risk and Capital Structure: A Conceptual Review of Theoretical and Empirical Research on Islamic Banking Perspective
}

Tengku Wasimah Raja Harun, Nazrol Kamil Mustaffa Kamil, Razali Haron, Zulkufly Ramly

To Link this Article: http://dx.doi.org/10.6007/IJARAFMS/v11-i3/11161 DOI:10.6007/IJARAFMS /v11-i3/11161

Received: 18 July 2021, Revised: 22 August 2021, Accepted: 10 September 2021

Published Online: 29 September 2021

In-Text Citation: (Harun et al., 2021)

To Cite this Article: Harun, T. W. R., Kamil, N. K. M., Haron, R., \& Ramly, Z. (2021). Bank Liquidity Risk and Capital Structure: A Conceptual Review of Theoretical and Empirical Research on Islamic Banking Perspective. International Journal of Academic Research in Accounting Finance and Management Sciences, 11(3), 539-553.

\section{Copyright: (C) 2021 The Author(s)}

Published by Human Resource Management Academic Research Society (www.hrmars.com)

This article is published under the Creative Commons Attribution (CC BY 4.0) license. Anyone may reproduce, distribute, translate and create derivative works of this article (for both commercial and non-commercial purposes), subject to full attribution to the original publication and authors. The full terms of this license may be seen at: http://creativecommons.org/licences/by/4.0/legalcode

Vol. 11, No. 3, 2021, Pg. 539 - 553 


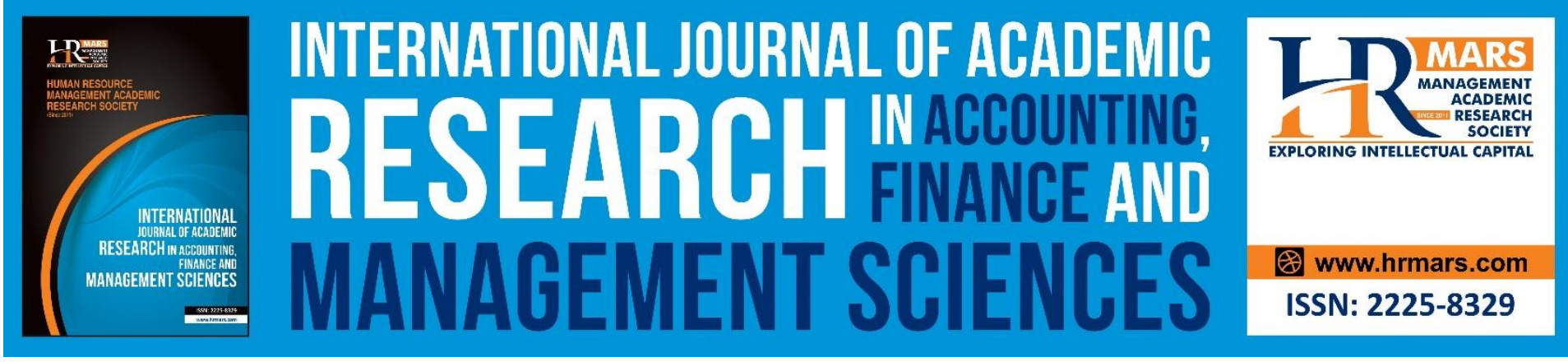

\title{
Bank Liquidity Risk and Capital Structure: A Conceptual Review of Theoretical and Empirical Research on Islamic Banking Perspective
}

\section{Tengku Wasimah Raja Harun', Nazrol Kamil Mustaffa Kamil², Razali Haron 3 , Zulkufly Ramly ${ }^{4}$}

${ }^{1}$ Kulliyyah of Economics and Management Sciences, International Islamic University Malaysia (IIUM) and Islamic Business School, Northern University of Malaysia (UUM), ${ }^{2,4}$ Kulliyyah of

Economics and Management Sciences, International Islamic University Malaysia (IIUM), Malaysia, ${ }^{3}$ Institute of Islamic Banking and Finance, International Islamic University Malaysia (IIUM), Malaysia

Email: tgwasimah@gmail.com/ wasimah@uum.edu.my

\begin{abstract}
This paper conducts a comprehensive review of relevant empirical literature on the impact of capital structure on bank's liquidity risk. Based on the existing literature, capital structure has a considerable impact on banks' liquidity risk either in positive or negative thought. However, we discover that empirical evidence on all of this relationship is heavily skewed in favour of conventional banks and firm's perspective. As a result, we urge that further research should be done in this area specifically in Islamic banking standpoint in order to gain a better understanding of the impact of capital structure on banks liquidity risk. This is due to the fact that the optimal capital structure for bank will trade-off the effects of bank capital specifically on the liquidity creation. Therefore, it is hoped that this paper can give a guideline to the policymakers, banking regulators, shareholders and other stakeholders to balance between capital structure and liquidity creation in order to evade from the issues of bank run and insolvency.
\end{abstract}

Keywords: Islamic Banking, Liquidity Risk, Capital Structure, Empirical, Theory

\section{Introduction}

Since the aftermath of the 2007-2008 Global Financial Crisis, bank's liquidity has been one of the most fascinating topics in the field of banking and finance. This is because the ample liquidity at United States banks fuelled the increased risk-taking that led to the Global Financial Crisis (GFC) occurred. Furthermore, during the crisis, liquidity risk was identified as one of the primary causes that contributed to the failure of banks all over the world. Due to this, Basel Committee on Banking Supervision (BCBS) as a policy maker introduced new regulation on liquidity in order to evade liquidity risk and limit the possibility of a bank run to enable banks to be more stable in the market (BCBS, 2010). 
MANAGEMENT SCIENCES

Vol. 11 , No. 3, 2021, E-ISSN: 2225-8329 @ 2021 HRMARS

The liquidity measures are founded on the conviction that banks need sufficient liquid assets to retain its intermediary function in the event of external shocks that could affect the economy as a whole (Kim \& Sohn, 2017). This could thus affect a wide range of banking activities, in particular banks as liquidity providers through the lending and borrowing transaction (DeYoung, Distinguin \& Tarazi, 2018). After a negative shock to their liquidity situation, banks could tighten lending rules, therefore reducing the credit scale for the economy. But how liquidity affects banking conduct is likewise regarded to be unsure (Roulet, 2018).

Similarly, academic scholars have emphasised the importance of banks to ensure the sufficiency of liquidity in order to avoid from the issue of bank run. For example, Ali (2006) stated that banks might confront with liquidity risk in the circumstance that banks are unable to meet with their short-term obligation such as to meet the demand for withdrawal needs. Also, scholar such as Ayub (2017) have divergent view on liquidity risk in which liquidity risk arise due to the wrong assumptions and improper decisions about higher earnings which fail in the payment system because of integrity and malfeasance.

Based on theory, banks produce liquidity to supply sufficient money to clients or depositors (Diamond, 1984). Moreover, bank employ its function as a risk transfer might convert risk by expanding riskless deposits to finance risky investment while at the same time generate profit (Mairafi, Hassan \& Arshad, 2018). Thus, the bank shall preserve a sufficient amount of liquidity to enable them to meet with the obligations and at the same time must protect the availability of cash and cash equivalents to ensure the issues of bank run not exist (Diamond, 1984).

Extant literature provided different views on the bank liquidity. Also, the studies focus more on the important factors affecting liquidity risk which led to the scantiness of studies on the issue of bank liquidity which link to the capital structure. For instance, studies by Akhtar et al (2011); Iqbal (2012); Ramzan \& Zafar (2012); Ahmed et al (2011); Amin et al (2017); AlHarbi (2017) provided and empirical benchmarks for considering the major factors or determinants of bank liquidity risk. They found that liquidity risk is positively correlated with bank profitability, bank size, financial leverage and capital adequacy.

Other studies by Sibilkov (2009); Sarlija \& Harc (2012); Khanqah \& Admadnia (2013); Burksaitiene \& Draugele (2018); Bukair (2019); Sumani \& Roziq (2020) provided divergent views on liquidity risk. Accordingly, these studies are of the view that capital structure give a significant influence towards the liquidity risk despites of the common major factors discuss in the most past literatures. This is due to the fact that, by providing appropriate capitalisation and higher liquidity creation, bank could have less damage from financial distress, as the risk are sufficiently covered (Diamond \& Rajan, 2000). However, most of these studies discuss the relationship between capital structure and liquidity risk in the perspective of firms. To the best of authors' knowledge, there is quite limited studies conducted on banking point of view. Thus, this motivate the authors to carried out some review on previous studies regarding to this relationship.

In this paper, we shed light on this issue by providing a review on theoretical and empirical studies on past liquidity risk and the impact of capital structure on liquidity risk in order to show other directions for future research. This would provide more insight into numerous aspects affecting liquidity risk of banks in order to provide guideline to researchers, policymakers and other stakeholders. This paper deals exclusively with empirical studies, which focus on liquidity risk and capital structure, in which researchers can use for further readings. Thus, the objectives of this article are as follows: 
1. To review the concept of liquidity risk and theoretical intuition between liquidity risk and capital structure.

2. To assess the previous studies on the determinants of liquidity risk.

3. To review the relationship between liquidity risk and capital structure based on the findings from previous studies.

Our paper is a bit differs from existing literature survey that focused mainly on determinants of banks' liquidity risk. However, limited studies focused on the association between the capital structure impact on the bank liquidity risk. Also, this paper focuses more on recent studies on bank liquidity risk and capital structure. The rest of the paper proceeds are as follows: the concept of bank liquidity risk, theoretical intuition on liquidity risk and capital structure, as well as empirical insight on bank liquidity risk which split into two subtopic, which are; i) past studies on liquidity risk, and ii) the impact of capital structure on bank liquidity risk. Finally, concludes the study.

\section{The Concept of Bank Liquidity Risk}

According to Banque De France (2008), the definition of liquidity is quite vague since it has many ways to define liquidity. In another point of view, liquidity is a notion that is not only difficult to define since the definition are vary depending on the situation but at the same time, it also difficult to be ignored (Calvo, 2013). In economics perspective, liquidity refers to the situation in which the asset can be easily converted into another such as cash or cash equivalent asset (Iqbal \& Mirakhor, 2011; Ali, 2013; Hasan, 2014; Sanghani, 2014). This can be illustrated where a car has lower liquidity compared to gold, and treasury bills have higher liquidity compared to corporate bonds. However, cash in terms of money seems to be the most liquid assets as it can easily converted into other assets without query (Hasan, 2014).

In banking point of view, banks are prone to deal with cash as the tools of liquidity since banks operate on a fractional reserve principle in which there is a trade-off between liquidity and profit. Basically, liquidity is necessary for banks in order to encounter any shortcoming either expected or unexpected in the balance sheet. Higher in liquidity indicated the bank's ability to transform its asset into cash quickly in order to meet the demand from the withdrawer. Lack of liquidity might give an adverse impact to the bank's ability in managing portfolios. The above statement is supported by Ali (2006) where bank might confront with liquidity risk in the circumstance that banks are unable to meet the current obligation. The past experienced revealed that liquidity risk arise due to the incorrect supposition and inappropriate decision for higher earnings that flaws in failure of payment system due to deficiency of integrity and misconduct (Ayub, 2017).

In practice, the differences between the Islamic and conventional banks are comparatively small in which Islamic banks also confront with financial distress even though Islamic banks do not deal with the element of interest. Although, Islamic banks seem to have more liquidity compared to conventional banks, there is an evidence indicate that Islamic bank were forced to shut down their operation such as the Islamic financial institution in Turkey, Ihlas Finance House, was enforced to shut down its operation in 2001 due to financial distress that arise from liquidity problem (Ali, 2006). Due to this, the issue of liquidity management become one of the significant alarms to both Islamic and conventional banks where the institutions were trigger to avoid from liquidity deficiency (Ayub, 2017).

According to Islamic Financial Service Board (IFSB, 2015) revealed that Islamic banks confront with liquidity risk due to several factors, such as:

i. The lack of Shariah-compliant liquidity instrument 
MANAGEMENT SCIENCES

Vol. 11 , No. 3, 2021, E-ISSN: 2225-8329 @ 2021 HRMARS

ii. Limited of debt transfer as Islamic banks need to comply with Shariahcompliant

iii. Insufficient of secondary market activity

iv. Lack of accessible tools to supervisory authorities for providing liquidity support to IIFS either in standard or tight market conditions

v. The absence of Shariah-compliant open market operations

Due to the above factors, the Islamic banks need to maintain an excessive cash and need to have high-quality liquid assets (HQLA) as compatible with the conventional. Due to the requirement to maintain sufficient liquid assets in order to support banks' daily operation, these factors have given an impact to the performance and competitiveness towards Islamic banks with conventional banks (IFSB, 2015).

The lack of Shariah-compliant liquidity instrument and insufficient access to secondary market activity also has been discussed by Ariffin (2012) as well as Mohammad and Shahwan (2013) where the authors stated that these factors become main issue that lead to liquidity risk. This is because the financial instruments are not sufficient enough to permit Islamic banks raise fund when needed. Meanwhile, in contrast to conventional, the financial instruments are based on interest and the banks do not bond with any Shariah rulings. For instance, Islamic banks commonly rely on commodity Murabahah or mark-up basis based on Tawarruq contract for short-term investment in order to meet liquidity requirement. However, many scholars dispute this arrangement because the legislation have still to be clarified or unclear. Due to this, other Shariah-compatible contract such as sukuk have been announced as one of the liquidity tools. The application of sukuk structure enable Islamic banks to buy or sell sukuk reliant to the liquidity position and pay or obtain profit in return (Ariffin, 2012). In addition, Ayub (2007) suggest that another contract such as Mudharabah, ljarah and parallel Salam also should be included as one of the Islamic bank's liquidity tools.

As one of the financial institutions, Islamic bank is often debated as an institution that prone to face with liquidity problem (Ray, 1995) and is one of the stunted factors in development of growth (Vogel \& Hayes, 1998). This can be seen in terms of the diversity of contract that are easily diluted very limited compared to conventional banks (Mohamad et al., 2013). This is because the nature of Islamic banking itself where all operation should be free from the element of interest and prevent the bank from fulfilling liquidity requirement easily as implemented by the conventional banks (Ariffin, 2012).

According to Ismal (2010), stated that Islamic banking needs to meet specific or unique characteristics related to risk profile and Shariah ruling before issuing any method in liquidity management. This matter should be emphasized to avoid any issues such as issues related to usury or interest in meeting the requirement of liquidity risk which is based on Shariah conjunction (Ismal, 2010). For instance, Islamic bank is not allowed to make borrowing at short notice through discounting debt obligation receivables and also does not have a lender of the last resort facility based on Shariah ruling (Ariffin, 2012). This means, Islamic banking is exposed to liquidity risk because banks are bound in investment that are non-liquid assets such as ljarah assets and also profit-sharing arrangements in Mudharabah or Musyarakah contract.

In place of the liquidation issue has been one of the utmost concerns among banks, Basel III provide rule regarding to liquidity where banks are necessitated to hold a liquid asset buffer and need to have high-quality liquid assets in order to avoid from liquidity shortage (Ayub, 2017). This means that the assets must be in a state that is easy to access and also easy to 
MANAGEMENT SCIENCES

Vol. 11, No. 3, 2021, E-ISSN: 2225-8329 @ 2021 HRMARS

dilute in order to meet liquidity requirement when needed. Likewise, Bank for International Settlement (BIS) also mentioned that the issues of liquidity have become a vital concern among the international policymakers as it can reflect the financial stability of a country (BCBS, 2008). The effective management of liquidity risk can enhance the ability of banks to meet with cash flow obligations and also can avoid from financial distress.

\section{Theoretical Intuition on Liquidity Risk and Capital Structure}

According to the theory of financial intermediation, there are two significant areas to the roles of banks which include liquidity creation and delegated monitoring (Diamond, 1984; Berger \& Bouwman, 2009). The roles of banks as intermediaries enables to overcome the problem of information asymmetries and reduced cost of exchange between borrowers and lenders (Pagano, 2011). The intermediaries' function is to counter the market imperfection issues related to the different perception between lenders and borrowers which might lead to the moral hazard or adverse selection (Khaldi \& Hamdouni, 2011).

Diamond (1984) demonstrate that banks create liquidity in order to provide customers or depositors with sufficient money for withdrawal needs. In addition, banks transform risk by increasing riskless deposits in order to finance risky investment portfolio while generating returns from the function of risk transfer (Mairafi et al., 2018). In this circumstance, bank must retain adequate amount of liquidity to fulfil their obligations promptly. Furthermore, bank must be able to guarantee the fast and efficient liquidity creation by safeguarding cash and cash equivalents against liquidity deficit (Diamond, 1984; Mairafi et al., 2018).

As liquidity played a significant role during the global financial crisis $2007-2009$, most banks have suffered as a result of the lack of wise management of cash flows. Concerning to this matter, new regulatory liquidity standards have been proposed by Basel Committee on Banking Supervision to complement the new capital framework. It is aiming to improve liquidity requirement in order to avoid from the banks to take an assertive transformation of liquidity which might lead to excessive liquidity risk (Acosta-Smith, Arnould, Milonas \& Vo, 2019). As pointed by Diamond and Rajan (2000), increase in bank capital can reduces liquidity creation by the banks and allow banks to survive in the market and evade financial distress.

It can be argued that banks do not purely independently optimise their liquidity choices. Any bank can have incentives to use similar techniques when other banks are willing to take more risk (Bonfim \& Kim, 2012). Due to the explicit or implicit commitment of the lender of last resort, such collective risk-taking techniques may be ideal on an individual basis and enable banks to boost profitability without increased the probability of insolvency.

Basically, banks can generate liquidity due to its deposits are delicate and inclined to runs. Furthermore, in the circumstance that uncertainty increased, this will make the deposits extremely delicate in which case there is a role for outside bank capital (Diamond \& Rajan, 2000). Increased in bank capital would result decrease in liquidity in which facilitates the banks to sustain in the industry and at the same time, banks can avoid the financial distress. Diamond and Rajan (2000) also mentioned that the optimal capital structure for bank will trade off the effects of bank capital specifically on the creation of liquidity, the cost of distress faced by banks, and also the ease of forcing repayment from the debtors.

In the event of a tough capital raise conditions, banks could retain a buffer stock of liquid assets to avoid inadequate cash or to enable possible lending in time (Fama, 2013). Although banks provide borrowers high liquidity, credit is badly liquid assets for banks. They may swap credits to meet liquidity standards, but this is quite difficult if market conditions are not conducive (Sawada, 2010). According to Diamond and Rajan (2000), in the 
MANAGEMENT SCIENCES

Vol. 11, No. 3, 2021, E-ISSN: 2225-8329 @ 2021 HRMARS

circumstance that liquidity demand increases in future, banks will tend to constrain their credit expansion. In other point of view, banks can be assumed to have more incentives to grow their loans if there is sufficient liquidity, especially to give immediate cash to depositors (Dang, 2021).

According to Acosta-Smith et al (2019), the bank capital can have an impact on the liquidity risk via two canals. The role of capital in absorbing losses is fall under the first canal. Since capital serves as a buffer that can absorb possible losses, higher-capital banks supposedly to be less exposed to liquidation. Meanwhile, the second canal is known as incentive canal. This can be implemented by encouraging a bank capital change to manage a bank's liquidity risk. The past study conducted by Gomez and Vo (2019) indicated that bank prefer to encounter their liquidity risk cautiously in a situation where their leverage is low. Gomez and Vo (2019) has come up with a model where banks can encounter their liquidity risk standing through the assessment of their liquid asset. In this circumstance, banks seem to hold an adequate buffer of liquid asset in order to absorb any losses arise from liquidity risk.

On the other hand, the notion of delegated surveillance indicated that banks play as delegated supervisors in investing in their customer's behalf (Diamond, 1984). This function could lead to an issue with the agency, as indicated by the agency theory and the conflict of interest between capital providers and company supervisors (Jensen \& Meckling, 1976). According to Sarker (2000), the agency problem arises due to the asymmetric information and high monitoring costs. Whereas, Aggrawal and Yousef (2000) found that the tendency of bank to utilize debt financing was due to an increase of agency costs. Due to the profit-sharing contract, the entrepreneurs or mudharib have high incentives to increase costs through increased personal benefits (Sanusi, 2002). Meanwhile, Ramly (1995) and Aggrawal and Yousef (2000) further examine this asymmetric information problem caused by moral hazard and adverse selection in Mudharabah financing.

Moral hazard occurs after the transaction is made (Khaldi \& Hamdouni, 2011) where there is inefficiency of banks as a capital provider to choose an entrepreneur or mudharib prioritizes private benefits by utilizing investment equipment and expenses for personal gain. The capital supplied is not used efficiently as what agreed in the contract and the trustworthiness of the entrepreneur are dubious. While the adverse selection problem arises before the transaction occurs (Khaldi \& Hamdouni, 2011) when the bank decides to carry out high risk projects managed by the entrepreneur who do not have experience in business and lack of skills in entrepreneurship. Since banks as a capital provider had incur a higher cost, the banks are enforcing to find alternatives by replacing the previous entrepreneur in order to ensure the continuity of the project or investments. Due to this, the Islamic banks also have a possibility to confront with failure as similar to the conventional banks. Therefore, banks should conduct their operation robustly in which banks need to manage and allocate their sources correctly and utilize the sources wisely with reasonable risk. By doing so, banks can enhance their liquidity standing and can uplift the creditworthiness among the borrowers and investors (Sahyouni \& Wang, 2019).

\section{Empirical Insight on Bank Liquidity Risk}

In modern economic world, the banking system plays a quite significant role. The existence of a bank not only supports a country in promoting its economic growth, but also transform it into a state-owned agency by giving a great impact on economic well-being (Suyanto, 2021). According to Mohammad (2013), one of the most vital functions of banks is the ability to 
MANAGEMENT SCIENCES

Vol. 11, No. 3, 2021, E-ISSN: 2225-8329 @ 2021 HRMARS

acquire funds from short-term deposits so as to finance credits in a long-term period. Due to this role, banks are prone to confront with liquidity risk (Berger \& Bouwman, 2009). This is due to the fact that liquidity and solvency of banks are closely related (Ariffin, 2012). This means, banks that have a better liquidity control can reduce the risk of banks to face with financial distress and have lower possibility to be insolvent.

Basel Committee on Banking Supervision (2008) states that bank liquidity is referring to the capability of bank to increase fund in assets and of satisfying commitments as they arise without inadmissible losses. The definition laid down by BCBS integrated the liquidity creation and liquidity risk, because their primary position as financial intermediaries exposes them inevitably to the liquidity risk. Thus, in this paper, we discuss the empirical research on liquidity risk into two subtopics, namely; 1 ) past studies of liquidity risk, and 2) the impact of capital structure on liquidity risk.

\section{Past Studies of Liquidity Risk}

Notwithstanding many of past literature conducted on conventional banking stated that conventional banking structure is more fragile to run compared to Islamic banking system (Samad \& Hassan, 2006; Beck et al., 2013). However, the fact revealed that Islamic banking also suffered with financial distress (Rizkiah, 2018). The well-known case of Islamic banking run occurred in Turkey which known as Ihlas Finance House (Hayali et al., 2012). From the case, many researchers started to investigate on why this issue happen and relate it with liquidity problem. According to Amin et al. (2017), most of the previous study on liquidity risk are commonly conducted on conventional point of view and only recently some studies documented on Islamic banking perspective.

The strand of literature shows that many studies regarding to the determinants of liquidity risk has been conducted on Pakistani Islamic banks. The studies demonstrate major liquidity risk factors, for instance profitability (Akhtar et al., 2011; Iqbal, 2012), size (Iqbal, 2012; Ramzan \& Zafar, 2012), financial leverage (Ahmed et al., 2011; lqbal, 2012), capital adequacy (Iqbal, 2012), and tangibility and age (Ahmed et al., 2012). At the same moment, Muharam and Kurnia (2012) conducted a study on Islamic banks liquidity risk in Indonesia and found that there is a positively significant by profitability factors which measure via return on asset (ROA) and return on equity (ROE), while capital adequacy indicated negative relationship which contradict to lqbal (2012).

Meanwhile, liquidity risk of Islamic banks in Malaysia indicated positive relationship by profitability, growth of GDP, size and short-term interest rate. However, some indicators revealed negative relationship towards liquidity risk such as financing, capital adequacy ratio and inflation rate (Mohamad et al., 2013). A negative relationship between CAR and inflation also can be found in Al-Harbi (2017). While some studies found that capital adequacy ratio indicated a significant positive relationship towards liquidity risk (Ghenimi \& Omri, 2015; Effendi \& Disman, 2017; Linh et al., 2018). However, Linh et al. (2018) found inflation rate is negatively correlated to liquidity risk which is parallel to Mohamad et al. (2013).

A study on liquidity risk in Islamic banking was also conducted involving several countries within a scope of study. For instance, Alman and Oehler (2010) performed a study involved Gulf Cooperation Countries (GCC), Southeast Asia, Brunei, Turkey and Egypt showed that liquidity transformation of Islamic banks in these countries is negatively influenced by risk, interbank requirements and leverage. While, in the scope of GCC countries, Al-Khouri (2012) has documented that capital, return on assets and bank size become the main factors affecting liquidity transformation in these countries. The author claimed that large banks with 
MANAGEMENT SCIENCES

Vol. 11, No. 3, 2021, E-ISSN: 2225-8329 @ 2021 HRMARS

excessive capital supply deem to provide more liquidity for banks though profitability decrease the liquidity created.

In the meantime, a liquidity risk study was also conducted in a comparison between Islamic and conventional banking involving GCC countries. This study can be found in Ghenimi and Omri (2015) indicated that bank size, ROA, ROE, net interest margin, capital adequacy ratio and inflation are positively correlated to liquidity risk. This finding is consistent with conventional banks excepts GDP growth has a negative and no significant impact on liquidity risk. The result of negative impact of growth of GDP is contradict to Jaara et al. (2017) as their study showed a positive relationship to liquidity risk for a comparative study with conventional banks in MENA and SEA region.

A study by Al-Harbi (2017) employed the ordinary least-square (OLS) fixed effect model in examining liquidity risk determinants for Islamic banks in OIC countries from 1989 to 2008. It was discovered that efficiency, off-balance sheet, profitability, size, market capitalization, concentration is positively significant to liquidity risk. While, capital, foreign ownership, credit risk, GDP, inflation, monetary policy, deposit insurance is negatively significant to liquidity risk.

Another study by Amin et al. (2017) employed GMM approach in investigative relationship between the effect of cost efficiency on liquidity risk on OIC Islamic banks from 1999 to 2013. This study revealed that all risk factors and cost efficiency is simultaneously determined. The factors such as cost efficiency, capital, bank specialization, credit risk, profitability, size, GDP and inflation show positive impact to liquidity risk. With respect to the link between liquidity risk and market concentration, it shows not significant relationship among them. The authors claimed that the smaller and less-developed structure of the banking system in emerging countries is likely to explain the insignificant relationship found in this study that lead market concentration not effective to give impact to liquidity risk.

\section{The Impact of Capital Structure on Bank Liquidity Risk}

One of the important decisions in the corporate finance fields is the capital structure which refers to the way a firm finances its assets through merging debts and equity (Keown et al., 1985; Gitman \& Zutter, 2012; Gul \& Cho, 2019). In other words, when a company or institution decides to expand its operation or market, it needs some sort of capital and this may be in the form of debt or equity. Generally, making ineffective decisions about capital structure can cause firms to face financial problems and eventually bankruptcy. The firm's management establishes capital structure in order to maximize the value of firms (Alipour et al., 2015).

Accordingly, other strand of literature focused on the impact of capital structure on the bank liquidity risk. This is because of the significant specific characteristics of the banking sector. For instance, the sum of capital influences the number of banks can cause borrower to pay their obligation. As increased capital reduces the creation of credit by banks, the bank can ask the borrowers to pay their liquidity requirement on time. Nevertheless, a bank may face lower impact of financial distress by being sufficiently capitalised and higher liquidity creation as the risks are sufficiently covered (Diamond \& Rajan, 2000).

Classically, banks hold capital to act as buffer in order to avoid liquidation or solvency. At the same time, banks hold liquid assets such as cash and securities in order to safe guard against sudden withdrawals by the depositors or commonly known as bank run (Saidbenberg \& Strahan, 1999). This is in line with Acosta-Smith et al. (2019) where banks need to hold large amount of liquid assets since it is less profitable than illiquid assets. Due to this, it will be fairly costly for a bank with small amount of capital to cover liquidity risk, which encourage the 
bank to confront with excessive liquidity risk. Therefore, banks' liquidity allows for further understanding of the potential relationship between liquidity risk and capital structure as there is increasing interest in literature (Sibilkov, 2009; Sarlija \& Harc, 2012; Khanqah \& Admadnia, 2013; Burksaitiene \& Draugele, 2018; Bukair, 2019; Sumani \& Roziq, 2020).

For example, Sarlija and Harc (2012) investigate the impact of liquidity on the Croatian firm's capital structure. In this study, there are several proxies used to measure the liquidity ratio such as current ratio, quick ratio and cash ratio. While, for leverage proxies, three proxies used such as debt ratio, debt to equity ratio and debt factor. The finding shows that all the proxies of capital structure are statistically significant negative association to all proxies of liquidity ratios. Meanwhile, cash ratio reported no significant effect on leverage proxied by long-term debt ratio This study can be concluded that firms that hold more liquidity can be less leveraged. However, this finding is inverse to Sibilkov (2009) where this study revealed there is a positive relationship between capital structure and liquidity of United States public companies. The author claimed that firms with more liquid may be found to be more leveraged. In the circumstance if the firm are unable to perform its obligation on liabilities, the firm is in the safe state as they have sufficient liquid assets to cover their debts (Sibilkov, 2009).

Similarly, a study by Khanqah and Admadnia (2013) study the impact of capital structure on liquidity of firms listed in Tehran Stock Exchange (TSE). In this study, leverage (total debt / total capital) is used as a proxy for capital structure. While, cash flows to assets' ratio, cash flows to net income and the ratio of cash flows to equity act as proxies for liquidity measurement. The result shows that leverage has an adverse significant relationship to cash flow to assets which means, increase in long-term liabilities will decrease the value of cash flow to assets of firms. Meanwhile, a significant positive relationship between leverage and cash flow to net income and cash flow to equity ratio. This means increase in liabilities of firm will increase the value of cash flow to net income and cash flow to equity ratio Khanqah and Admadnia (2013). According to static trade-off theory by Bradley, Jarrell and Kim (1984), more liabilities are used in those firms which are more liquid. Furthermore, debt act as control tool to avoid the use of free cash. Based on Hung and Sung (2006), higher portion of liabilities can therefore bound firm's manager with greater liquidity and profitability.

Another study by Burksaitiene and Draugele (2018) investigate the relationship between capital structure and liquidity of firms in Baltic countries. In this study, three proxies of capital structure used such as equity ratio, debt capital ratio and leverage ratio. While for liquidity, current ratio, quick ratio and liquidity ratio has been used to study the impact of these relationship. The result indicated that a negative relationship between capital structure ratios and liquidity ratios which implies the more capital is used by the firm's equity structure, the lower the liquidity risk of firms, while the greater the debt capital, the higher the risk face by the firms. In addition, the current ratio and quick ratio is also strongly negative relationship to liquidity. This means, the higher amount of external debt such as interest payments could pose a potential hazard of scarcity of cash which could be decisive to the firm.

Bukair (2019) used current account over total assets for leverage proxy, while current ratio (liquid asset / total assets) for liquidity proxy in order to determine both relationships. The liquidity proxy used in this study is similarly used by Akhtar et al. (2011) and Iqbal (2012) in their research. Before the analysis was made, Bukair (2019) expected that there was a positive relationship between these two variables. Fortunately, after analysis was made via Generalized Least Square (GLS) regression, liquidity become one of the most important factors of Islamic banks capital structure in GCC countries with a positive significant value. 
MANAGEMENT SCIENCES

Vol. 11, No. 3, 2021, E-ISSN: 2225-8329 @ 2021 HRMARS

The result of this study conforms to the hypothesis that was made during the beginning of the study. This result is consistent with Sibilkov (2009) and Ahmed et al. (2011). Bukair (2019) explained that high-level liquidity hold by Islamic banks might lead to lower risk in which allows managers to increase their shareholder interest instead of creditors by reducing the cost of debt. Furthermore, holding more cash can give advantage to banks by lending more and increasing levies in the credit market.

Latest study by Sumani and Roziq (2020) examine the relationship between capital structure and liquidity policy on manufacturing companies listing on the Indonesian Stock Exchange. The result documented that capital structure has a significant positive impact on liquidity. This result is parallel to Sibilkov (2009) and Bukair (2019) even though they are from different sample of study. Sumani and Roziq (2020) provide their stand where firms with highdebt level prone to have high cost of capital and might contribute to the reduction of firm's profitability. In the event of decreasing in profitability, it can lead to declining of cash flow in which firms will utilize cash holdings, liquid assets and cash in order to cover the cost of capital. This might lead the firms to face with the risk of insolvency and firms need to prepared considerable funds beforehand to protect from insolvency.

\section{Conclusion and Recommendation}

The matter of liquidity and its impact on banks has piqued attention in the banking and financial literature, although empirical evidence focuses primarily on the major factor affecting the liquidity risk of banks, yet there are few empirical studies from the capital structure perspectives. Based on this, we carried out a review on studies on majoring effects of liquidity risk on banks and how the capital structure can also give impact to the liquidity risk. From the previous studies, liquidity risk is commonly being affected by several factors such as profitability, size, capital adequacy, growth of GDP, inflation rate and short-term interest rate either direct or indirectly. However, there is limited studies has been conducted in measuring the relationship between capital structure and liquidity risk. Based on theory, the optimal capital structure for a bank will balance the benefits of capital on liquidity creation, the cost of distress for banks, and the ease of getting debtors to repay. Therefore, as of the comprehensive review from the literature, it shows that capital structure gives a significant impact to the liquidity risk. The relationship between each proxies of capital structure such as debt ratio or leverage ratio is positively or negatively correlated to liquidity risk which measure by liquidity ratios. This shows that, in the circumstance where the risks are adequately covered, a bank's capitalisation and liquidity creation may be less affected by financial distress.

Although the banks are major liquidity providers in the economy, banks must manage their balance sheet structure efficiently by managing the liquidity risk robustly, given the intrinsic irreversibility of their maturity transformation function. Banks can retain a liquid asset buffer to ease the maturity mismatch between assets and liabilities. In this sense, there is a need to limit liquidity risks is that banks do not take the societal optimum into account when optimising the risk and return relationship. Yet, bank failure can be an enormous externality for other banks and, eventually for the economy as a whole. Most of the existing studies on the association between liquidity risk and capital structure mainly focused on the firms' point of view. Hence, this paper points out the need to explore the nature of the relationship between liquidity risk and capital structure in general. It is suggested for further research to be conducted more on banking perspective as well as the comparative studies between Islamic and conventional banking system around the globe. Such studies can help 
MANAGEMENT SCIENCES

Vol. 11, No. 3, 2021, E-ISSN: 2225-8329 @ 2021 HRMARS

researchers to better understand the relationship between liquidity risk and capital structure in more depth, especially in terms of banking. It is also seen as very important in ensuring a stable position of the banking system in addressing the problem of imbalance between assets and liabilities to avoid problems such as liquidity risk arise. In addition, this type studies can give significant contribution to the literature and can help bank regulators or policymaker in making any decision on the related issues. Therefore, there is still an avenue for this article to be extended in the forthcoming, with more comprehensive literature and data, as well as reevaluate the relationship between liquidity risk and capital structure and how its impact might change the stability of the banking system.

\section{References}

Acosta-Smith, J., Arnould, G., Milonas, K., \& Vo, Q. A. (2019). Capital and Liquidity Interaction in Banking. Bank of England Working Papers , 1-41.

Aggarwal, R. K., \& Yousef, T. (2000). Islamic Banks and Investment Financing. Journal of Money, Credit and Banking, Vol. 32, No. 1, 93 - 120.

Ahmed, N., Ahmed, Z., \& Naqvi, I. H. (2011). Liquidity Risk and Islamic Banks: Evidence from Pakistan. Interdisciplinary Journal of Research in Business, Vol. 1, Issue. 9, 99 - 102.

Akhtar, M. F., Ali, K., \& Sadaqat, S. (2011). Liquidity Risk Management: A Comparative Study Between Conventional and Islamic Banks of Pakistan. Interdisciplinary Journal of Research in Business, Vol. 1, Issue. 1, 33 - 44.

Al-Harbi, A. (2017). Determinants of Banks Liquidity: Evidence From OIC Countries. Journal of Economic and Administrative Sciences, Vol. 33, No. 2, 164 - 177.

Ali, S. S. (2006). Financial Distress and Bank Failure: Lessons From Closure of Ihlas Finans in Turkey. Islamic Economic Studies, Vol. 14, No. 1 \& 2,, 1 - 52.

Ali, S. S. (2013). State of Liquidity Management in Islamic Financial Institutions. Is/amic Economic Studies, Vol. 21, No. 1, 63 - 98.

Alipour, M., Seddigh, M. F., \& Derakhshan, M. H. (2015). Determinants of Capital Structure: An Empirical Study of Firms in Iran. International Journal of Law and Management, Vol. 57 Iss 1, $53-83$.

Al-Khouri, R. (2012). Bank Characteristics and Liquidity Transformation: The Case of GCC Banks. International Journal of Economics and Finance; Vol. 4, No. 12, 114 - 120.

Alman, M., \& Oehler, A. (2012). Liquidity Transformation Factors of Islamic Banks: An Empirical Analysis. Bamberg: Bamberg University.

Amin, S. I., Mohamad, S., \& Shah, M. E. (2017). Does Cost Efficiency Affect Liquidity Risk in Banking? Evidence from Selected OIC Countries. Jurnal Ekonomi Malaysia, Vol. 51, Issue 2, 47 - 62.

Ariffin, N. M. (2012). Liquidity Risk Management And Financial Performance In Malaysia: Empirical Evidence From Islamic Banks. Aceh International Journal of Social Sciences, Vol. 1, Issue 2, 77 - 84.

Ayub, M. (2007). Understanding Islamic Finance. United Kingdom: John Wiley and Sons, Ltd. Ayub, M. (2017). Liquidity Management by Islamic Banks: An Issue or a Contrivance for RiskFree Returns. Journal of Islamic Business and Management. Vol. 7, Issue 1, 1 - 10.

Banque De France. (2008). Special Issue on Liquidity. Eurosysteme: Financial Stability Report.

BCBS, B. C. (2008). Principles for Sound Liquidity Risk Management and Supervision. Switzerland: Bank For International Settlements.

BCBS, B. C. (2010). Basel III: International Framework for Liquidity Risk Measurement, Standards and Monitoring. Switzerland: Bank For International Settlements. 
MANAGEMENT SCIENCES

Vol. 11, No. 3, 2021, E-ISSN: 2225-8329 ๔ 2021 HRMARS

Beck, T., Demirgüç-Kunt, A., \& Merrouche, O. (2013). Islamic vs. Conventional Banking: Business Model, Efficiency and Stability. Journal of Banking \& Finance, Vol. 37, Issue 2, $443-447$.

Berger, A. N., \& Bouwman, C. (2009). Bank Liquidity Creation. Review of Financial Studies, Vol. 22, Issue 9, 3779 - 3837.

Bonfim, D., \& Kim, M. (2012). Liquidity Risk in Banking Is There Herding. European Banking Center Discussion Paper No. 2012-024, 1-40.

Bukair, A. A. (2019). Factors Influencing Islamic Banks' Capital Structure in Developing Economies. Journal of Islamic Accounting and Business Research; Vol. 10, Issue 1, 2 20.

Burksaitiene, D., \& Draugele, L. (2018). Capital Strucutre Impact on Liquidity Management. International Journal of Economics, Business and Management Research, Vol. 2, No. 1, 110 - 127.

Calvo, G. (2013). Puzzling over the Anatomy of Crises: Liquidity and the Veil of Finance. Institute for Monetary and Economic Studies (IMES) Discussion Paper Series, 1 -27.

Dang, V. D. (2021). Bank Liquidity and Lending Behavior: Evidence From The Vietnamese Banking System. International Journal of Business and Society, Vol. 22, No. 1, 240 256.

DeYoung, R., Distinguin, I., \& Tarazi, A. (2018). The Joint Regulation of Bank Liquidity and Bank Capital. Journal of Financial Intermediation, Volume 34, 32 - 46.

Diamond, D. W. (1984). Financial Intermediation and Delegated Monitoring. The Review of Economic Studies, Volume 51, Issue 3, 393 - 414.

Diamond, D. W., \& Rajan, R. G. (2000). A Theory of Bank Capital. The Journal of Finance, 55(6), 2431-2465.

Effendi, K. A., \& Disman2, D. (2017). Liquidity Risk: Comparison between Islamic and Conventional Banking. European Research Studies Journal, Volume XX, Issue 2A, 308318.

Fama, E. F. (2013). Was There Ever a Lending Channel? European Financial Management, Vol. 15, Issue 5, 837 - 851.

Ghenimi, A., \& Omri, M. A. (2015). Liquidity Risk Management: A Comparative Study between Islamic and Conventional Banks. Arabian Journal of Business and Management Review; Vol. 5, Issue 6, 1-6.

Gitman, L. J., \& Zutter, C. J. (2012). Principles of Managerial Finance - Global Edition. United Kingdom: Pearson.

Gomez, F., \& Vo, Q.-A. (2019). Liquidity Management in Banking: the Role of Leverage. Bank of England Working Paper, 1 - 40.

Gul, S., \& Cho, H. R. (2019). Capital Structure and Default Risk: Evidence from Korean Stock Market. Journal of Asian Finance, Economics and Business, Vol. 6, No. 2 , 15 - 24.

Hasan, Z. (2014). Islamic Banking and Finance: An Integrative Approach. Malaysia: Oxford Fajar Sdn. Bhd.

Hayali, A., Sarili, S., \& Dinc, Y. (2012). Turkish Experience in Bank Shareholders' Fraud and Bank Failure: Imar Bank and Ihlas Finans Case. The Macrotheme Review, 115 - 129.

IFSB. (2015). Guidance Note on Quantitative Measures for Liquidity Risk Management in Institutions Offering Islamic Financial Services (Excluding Islamic Insurance (Takaful) Institutions and Islamic Collective Investment Schemes). Kuala Lumpur, Malaysia: Islamic Financial Services Board (IFSB). 
MANAGEMENT SCIENCES

Vol. 11, No. 3, 2021, E-ISSN: 2225-8329 @ 2021 HRMARS

Iqbal, A. (2012). Liquidity Risk Management: A Comparative Study between Conventional and Islamic Banks of Pakistan. Global Journal of Management and Business Research, Vol. 12, Issue 5, 54 - 64.

Iqbal, Z., \& Mirakhor, A. (2011). An Introduction to Islamic Finance: Theory and Practice. United Kingdom: John Wiley \& Sons (Asia) Pte. Ltd.

Ismal, R. (2010). Assessment of Liquidity Management in Islamic Banking Industry. International Journal of Islamic and Middle Eastern Finance and Management, Vol. 3 No. 2, 147 - 167.

Jaara, O. O., Jaara, B. O., Shamieh, J., \& Fendi, U. A. (2017). Liquidity Risk Exposure in Islamic and Conventional Banks. International Journal of Economics and Financial Issues, Vol. 7, Issue 6, 16 - 26.

Jensen, M. C., \& Meckling, W. H. (1976). Theory of the Firm: Managerial Behavior, Agency Costs and Ownership Structure. Journal of Financial Economics, Vol. 3, No. 4, 306 360.

Keown, A. J., Scott, D. F., Martin, J. D., \& Petty, J. W. (1985). Basic Financial Management. United Kingdom: Prentice-Hall: 3rd Edition.

Khaldi, K., \& Hamdouni, A. (2011). Islamic Financial Intermediation: Equity, Efficiency and Risk. International Research Journal of Finance and Economics, Issue 65, 145 - 160.

Khanqah, V. T., \& Ahmadnia, L. (2013). The Impact of Capital Structure on Liquidity and Investment Growth Opportunity in Tehran Stock Exchange. Journal of Basic and Applied Scientific Research; Vol. 3, Issue 4, 463 - 470.

Kim, D., \& Sohn, W. (2017). The Effect of Bank Capital on Lending: Does Liquidity Matter? Journal of Banking \& Finance, Vol. 77, Issue C, 95 - 107.

Linh, D. H., Dung, T. M., Hang, L. T., \& Mai, D. N. (2018). Determinants of Islamic Banks Liquidity and Lessons for Vietnam Banks. International Journal of Business, Economics and Law, Vol. 17, Issue 5,13 - 23.

Mairafi, S. L., Hassan, S., \& Mohamed-Arshad, S. B. (2018). Systematic Review of Literature on Effect of Liquidity on Bank. Academy of Accounting and Financial Studies Journal, Vol. 22, Issue 4, 1 - 7.

Mohamad, A. A., Mohamad, M. T., \& Samsudin, M. L. (2013). How Islamic Banks of Malaysia Managing Liquidity? An Emphasis on Confronting Economic Cycles. International Journal of Business and Social Science, Vol. 4 No. 7; 253 - 263.

Mohammad, M. O., \& Shahwan, S. H. (2013). The Objective of Islamic Economic and Islamic Banking in Light of Maqasid Al-Shariah: A Critical Review. Middle-East Journal of Scientific Research, Vol. 13, 75 - 84.

Muharam, H., \& Kurnia, H. P. (2012). The Influence of Fundamental Factors to Liquidity Risk on Banking Industry: Comparative Study Between ISlamic Bank and Conventional Bank in Indonesia. Proceeding of Conference in Business, Accounting and Management (CBAM), 359 - 368.

Ramly, S. A. (1995). Asset Management of Malaysian Islamic Bank: Problems on Mudharabah Banking. Journal IKIM 3 (2), 87 - 105.

Ramzan, M., \& Zafar, M. I. (2014). Liquidity Risk Management in Islamic Banks: A Study of Islamic Banks of Pakistan. Interdiciplinary Journal of Contemporary Research in Business, Vol. 5, No.12, 199-215.

Ray, N. D. (1995). Arab Islamic Banking and the Renewal of Islamic Law. London: Graham and Troutman Limited. 
MANAGEMENT SCIENCES

Vol. 11, No. 3, 2021, E-ISSN: 2225-8329 @ 2021 HRMARS

Rizkiah, S. K. (2018). Liquidity Management in Islamic Banking: Issues and Challenges. Tazkia Islamic Finance and Business Review, Volume 12, Issue 2, 131 - 152.

Roulet, C. (2018). Basel III: Effects of Capital and Liquidity Regulations on European Bank Lending. Journal of Economics and Business, Volume 95, 26 - 46.

Sahyouni, A., \& Wang, M. (2019). Liquidity Creation and Bank Performance: Evidence from MENA. ISRA International Journal of Islamic Finance, Vol. 11, No. 1, 27 - 45.

Saidbenberg, M. R., \& Strahan, P. E. (1999). Are Banks Still Important for Financing Large Businesses? Current Issues in Economics and Finance, 5(12), 1-6.

Samad, A., \& Hassan, M. K. (2006). The Performance of Malaysian Islamic Bank During 1984 1997: An Exploration Study. International Journal of Islamic Financial Services Vol. 1 No.3, 1 - 14.

Sanghani, D. A. (2014). The Effect of Liquidity on the Financial Performance of Non-Financial Companies Listed At the Nairobi Securities Exchange. Unpublished MBA Project.

Sanusi, N. A. (2002). Bukti Empirik Kajian Struktur Modal. Jurnal Ekonomi Malaysia, Vol.36, 39 $-67$.

Sarker, M. A. (2000). Islamic Business Contracts, Agency Problem and The Theory of the Islamic Firm. International Journal of Islamic Financial Services Vol. 1 No.2, 1 - 15.

Šarlija, N., \& Harc, M. (2012). The Impact of Liquidity on the Capital Structure: A Case Study of Croatian Firms. Business Systems Research, Vol. 3, No. 1, 30 -36.

Sawada, M. (2010). Liquidity Risk and Bank Portfolio Management in a Financial System Without Deposit Insurance: Empirical Evidence from Prewar Japan. Review of Economics and Finance, Vol. 19, Issue 3, 392 - 406.

Sibilkov, V. (2009). Asset Liquidity and Capital Structure. The Journal of Financial and Quantitative Analysis, Vol. 44, No. 5, 1173 - 1196.

Sumani, S., \& Roziq, A. (2020). Reciprocal Capital Structure and Liquidity Policy: Implementation of Corporate Governance toward Corporate Performance. Journal of Asian Finance, Economics and Business, Vol. 7 No. 9 , 085-093.

Suyanto, S. (2021). The Effect of Bad Credit and Liquidity on Bank Performance in Indonesia. Journal of Asian Finance, Economics and Business, Vol. 8, No. 3, 451 - 458.

Vogel, F., \& Hayes, S. (1998). Islamic Law and Finance: Religion, Risk and Return. The Hague: Kluwer Law Intl. 